\title{
PENGARUH KURS/ NILAI TUKAR RUPIAH, INFLASI DAN TINGKAT SUKU BUNGA SBI TERHADAP INDEKS HARGA SAHAM GABUNGAN LQ-45 PERIODE TAHUN 2009-2013
}

\author{
Maisaroh Fathul Ilmi \\ Prodi Akuntansi Universitas Negeri Yogyakarta \\ maisaroh.fathul@gmail.com
}

\begin{abstract}
Abstrak: Pengaruh Kurs/ Nilai Tukar Rupiah, Inflasi dan Tingkat Suku Bunga SBI Terhadap Indeks Harga Saham Gabungan LQ-45 Periode Tahun 2009-2013. Penelitian ini bertujuan mengetahui pengaruh Kurs/ Nilai Tukar Rupiah, Inflasi dan Tingkat Suku Bunga SBI terhadap IHS LQ-45 tahun 2009-2013. Teknik analisis data menggunakan statistik deskriptif, uji asumsi klasik, regresi linier sederhana, dan regresi linier berganda. Hasil penelitian menunjukkan bahwa: Kurs/ nilai tukar rupiah berpengaruh negatif dan signifikan terhadap IHS LQ-45, ditunjukkan dengan koefisien regresi sebesar $-0,117$ dan sig t $0,000<0,05$; Inflasi berpengaruh negatif dan tidak signifikan terhadap IHS LQ-45, ditunjukkan dengan koefisien regresi sebesar $-9,693$ dan sig t 0,446>0,05; Tingkat suku bunga SBI berpengaruh negatif dan signifikan terhadap IHS LQ-45, ditunjukkan dengan koefisien regresi sebesar $-87,152$ dan sig t 0,000<0,05; Kurs/ nilai tukar rupiah, inflasi, tingkat suku bunga SBI secara simultan berpengaruh signifikan terhadap IHS LQ-45 ditunjukkan dengan sig t 0,000<0,05.
\end{abstract}

Kata Kunci: Indeks Harga Saham LQ-45, Kurs/ Nilai Tukar Rupiah, Inflasi, dan Tingkat Suku Bunga SBI.

\begin{abstract}
Abstrack: The Influence of Exchange Rate, Inflation and SBI Interest Rate on LQ-45 Stock Price Index Year Period 2009-2013. The purpose of this research is to find out the influence of Exchange Rate, Inflation and SBI Interest Rate of LQ-45 Index year 2009-2013. Data analysis techniques applied are statistic descriptive, classic assumption test, simple linear regression, and multiple linier regression. Result from the research show that Exchange Rate has negative and significant influence on LQ-45 index shown by regression value $-0,117$ and sig $t$ 0,000<0,05; Inflation has negative and insignificant influence on $L Q-45$ index shown by regression value -9,693 and sig t 0,446>0,05; SBI Rate Interest has negative and significant influence on LQ-45 index shown by koeficient regression -87,152 and sig t 0,000>0,05; Exchange Rate, Inflation and SBI Interest Rate have significant influence on LQ-45 Index shown by sig t 0,000<0,05.
\end{abstract}

Keyword: LQ-45 Stock Price Index, Exchange Rate, Inflation, and SBI Interest Rate. 


\section{JURNAL NOMINAL / VOLUME VI NOMOR 1 / TAHUN 2017}

PENDAHULUAN

Pasar modal merupakan salah satu instrumen ekonomi yang mengalami perkembangan sangat pesat dewasa ini. Pasar modal dapat dijadikan indikator kemajuan suatu negara dan juga dapat menunjang ekonomi suatu negara. Pasar modal merupakan salah satu alternatif pilihan untuk berinvestasi yang dapat menghasilkan tingkat keuntungan optimal bagi para investor. Investasi adalah komitmen atas sejumlah dana atau sumberdaya lainnya yang dilakukan pada saat ini, dengan tujuan memperoleh sejumlah keuntungan dimasa datang (Tandelilin: 2007). Seorang investor membeli sejumlah saham dengan harapan memperoleh keuntungan untuk masa yang akan datang. Investasi terhadap saham mempunyai risiko yang lebih besar daripada investasi terhadap obligasi, deposito dan tabungan.

Salah satu kegiatan investasi yang dapat dipilih oleh investor adalah berinvestasi dipasar modal. Pasar modal di Indonesia merupakan salah satu dari berbagai alternatif bagi masyarakat yang kelebihan dana untuk berinvestasi. Banyak jenis surat berharga yang dijual dipasar tersebut, salah satunya adalah saham. Investor yang berminat berinvestasi dipasar modal dapat berinvestasi di Bursa Efek Indonesia (BEI).
Selain sebagai tempat untuk berinvestasi, pasar modal juga dapat mencerminkan kondisi perekonomian makro suatu negara yang dapat dilihat dari suatu Indeks Harga Saham. Indeks Harga Saham adalah suatu indikator yang menggambarkan pergerakan harga saham. Pergerakan indeks menggambarkan kondisi pasar pada saat pasar sedang aktif atau lesu. Menurut Darmaji dan Fakhruddin (2006:168) di Bursa Efek Indonesia (BEI) terdapat enam jenis indeks yaitu indeks individual, indeks harga saham sektoral, indeks harga saham gabungan (IHSG), indeks LQ 45, indeks syariah atau JII (jakarta Islamic Index) dan Indeks papan utama dan papan pengembangan. Melalui pergerakan indeks harga saham gabungan, investor dapat melihat apakah kondisi pasar sedang bergairah atau lesu.

Indeks LQ 45 merupakan indeks yang terbentuk hanya dari 45 jenis saham terpilih berdasarkan likuiditas pasar dan kapitalisasinya. Sedangkan Indeks Harga Saham Gabungan adalah indeks yang terbentuk dari seluruh harga saham yang terdaftar di Bursa Efek. Pergerakan IHSG secara siginifikan dapat dipengaruhi oleh Indeks Harga saham LQ 45 karena indeks LQ 45 merupakan gabungan harga saham yang berkapitalisasi besar, sedangkan pergerakan saham yang berkapitalisasi 


\section{JURNAL NOMINAL / VOLUME VI NOMOR 1 / TAHUN 2017}

kecil cenderung kurang mempengaruhi IHSG.

Menurut Halim (2005:12) Indeks harga saham (IHS) merupakan ringkasan dari pengaruh simultan dan kompleks dari berbagai macam variabel yang berpengaruh, terutama tentang kejadiankejadian ekonomi. Dengan demikian, IHS dapat dijadikan barometer kesehatan ekonomi suatu negara dan sebagai dasar melakukan analisis statistik atas kondisi pasar terakhir (current market). Kemampuan perusahaan dalam memperoleh laba tersebut tidak saja ditentukan oleh kemampuan manajemen dalam mengelola sumber daya yang ada, tetapi juga dipengaruhi oleh faktor lain diluar perusahaan, seperti kondisi sosial masyarakat, politik, dan keamanan. Semua itu akan berpengaruh terhadap kemampuan perusahaan dalam memperoleh laba, yang pada gilirannya akan berpengaruh juga terhadap fluktuasi harga saham.

Faktor-faktor ekonomi makro secara empiris telah terbukti mempunyai pengaruh terhadap perkembangan investasi di beberapa negara, seperti tingkat pertumbuhan Produk Domestik Bruto (PDB), laju pertumbuhan inflasi, tingkat suku bunga dan nilai tukar mata uang (Exchage Rate) ( Tandelilin, 2007: 216). Secara garis besar, faktor makro ekonomi yang mempegaruhi indeks harga saham dapat dikelompokkan menjadi dua yaitu faktor makro ekonomi yang berasal dari luar negeri dan faktor makro ekonomi yang berasal dari dalam negeri. Contoh faktor makro ekonomi dari luar negeri adalah Dow Jones Indeks, suku bunga The Fed, perubahan kurs/ nilai tukar rupiah, dan pergerakan harga emas dunia. Sedangkan inflasi, tingkat bunga, suku bunga sertifikat bank Indonesia (SBI), perubahan Produk Domestik Bruto (PDB) merupakan faktor makro ekonomi yang berasal dari dalam negeri.

Akhir-akhir ini industri di Indonesia mengalami perkembangan, perusahaanperusahaan di Indonesia aktif melakukan kegiatan ekspor dan impor. Salah satu faktor yang melancarkan kegiatan ekspor impor tersebut adalah dengan mata uang sebagai alat transaksi. Salah satu mata uang yang umum dan biasa digunakan dalam kegiatan ekspor impor adalah dollar Amerika. Bagi perusahaan-perusahaan yang aktif dalam kegiatan ekspor impor tersebut, kestabilan kurs dollar terhadap rupiah menjadi sangat penting.

Kurs adalah harga/nilai mata uang suatu negara dibandingkan dengan mata uang negara lain. Dalam hal penelitian ini kurs yang dimaksud adalah nilai rupiah terhadap dollar AS. Perubahan kurs dapat mempengaruhi kompetitifnya suatu suatu perusahaan. Flukstuasi nilai tukar/kurs dapat mempengaruhi pendapatan dan biaya operasional perusahaan dan pada ahirnya 


\section{JURNAL NOMINAL / VOLUME VI NOMOR 1 / TAHUN 2017}

dapat mempengaruhi harga saham suatu perusahaan. Selain itu untuk suatu negara yang ketergantungan impornya tinggi, penurunan kurs dapat menjadikan kekhawatiran mengenai akan adanya inflasi. Bahan baku impor yang tinggi akan mengakibatkan produsen menaikkan harga jual produknya, dan akhirnya akan berujung pada kenaikan harga barang atau inflasi. Selain itu dampak adanya inflasi yaitu meningkatnya suku bunga SBI. Dengan adanya inflasi, Bank Indonesia akan meningkatkan suku bunga SBI. Hal ini akan mengakibatkan banyak investor lebih tertarik dan mengalihkan investasinya untuk membeli SBI yang lebih bebas dari risiko dari pada saham. Hal ini akan mengakibatkan nilai saham menjadi turun dan akan diikuti pula oleh penurunan indeks harga saham gabungan.

Masalah inflasi sangat mudah sekali dialami oleh negara-negara yang sedang berkembang. Inflasi adalah kecenderungan dari harga-harga untuk menaik secara umum dan terus menerus (Boediono, 2005). Inflasi juga merupakan suatu keadaan melemahnya daya beli dan diikuti dengan merosotnya nilai riil mata uang. Dengan semakin tingginya angka inflasi, maka perekonomian akan memburuk, hal ini akan berdampak pada turunnya keuntungan suatu perusahaan, yang akan mengakibatkan pergerakan harga saham menjadi tidak kompetitif.
Suku bunga merupakan jumlah uang yang dibayarkan sebagai imbalan atas penggunaan utang. Suku bunga yang tinggi akan menimbulkan tingginya volume tabungan masyarakat. Semakin tinggi bunga yang ditawarkan oleh bank, akan semakin tinggi juga antusias masyarakat untuk menabung. Dengan demikian investor akan lebih memilih untuk menginvestasikan uangnya dalam bentuk tabungan atau deposito dari pada saham.

Pengamatan terhadap beberapa perubahan variabel makro ekonomi seperti PDB, inflasi, tingkat bunga ataupun nilai tukar mata uang, dipercaya dapat membantu investor dalam meramalkan perubahan yang akan terjadi pada pasar modal. Seperti contoh, variabel tingkat suku bunga dapat dipakai dalam meramalkan harga saham atau obligasi yang akan terjadi. Jika diramalkan tingkat suku bunga akan meningkat, maka dapat diperkirakan bahwa harga saham maupun obligasi cenderung menurun.

\section{METODE PENELITIAN}

\section{Jenis Penelitian}

Penelitian ini dikelompokkan ke dalam penelitian kausal komparatif yang merupakan penelitian ex post facto, yaitu tipe penelitian atas peristiwa yang telah terjadi di masa lalu untuk melacak faktorfaktor yang menyebabkan peristiwa tersebut. Jenis data yang digunakan dalam 
penelitian adalah data kuantitatif. Berdasarkan karakteristiknya, penelitian ini termasuk penelitian kausal komparatif.

\section{Tempat dan waktu penelitian}

Penelitian dilakukan dengan mengakses web resmi BEI yaitu www.idx.co.id, $\quad$ Bank Indonesia www.bi.go.id, dan Badan Pusat Statistik (BPS) yaitu www.bps.go.id,

\section{Populasi dan Sampel Penelitian}

Populasi pada penelitian ini adalah seluruh saham yang terdaftar di BEI. Sampel dalam penelitian ini adalah sahamsaham yang masuk dalam kriteria indeks harga saham LQ-45 periode tahun 20102013. Sedangkan data yang digunakan adalah data bulanan dari rata-rata Indeks Harga Saham LQ-45 selama 4,5 tahun sehingga jumlah observasi sebanyak 55 sampel.

\section{DEFINISI OPERASIONAL}

\section{VARIABEL}

\section{Variabel Dependen}

Variabel dependen dalam penelitian ini adalah Indeks Harga Saham Gabungan LQ-45. Indeks harga saham gabungan LQ45 adalah indeks saham yang dihitung dari 45 jenis saham dengan liquiditas tinggi dan kapitalisasi pasar yang besar.

\section{Variabel Independen}

1) Kurs/Nilai Tukar Mata Uang (X1)

Kurs/ Niali tukar mata uang adalah harga/nilai mata uang suatu negara dibandingkan dengan mata uang negara lain. Dalam hal penelitian ini kurs yang dimaksud adalah nilai rupiah terhadap dollar AS.

2) Inflasi (X2)

Inflasi adalah kecenderungan terjadinya peningkatan harga produkproduk secara keseluruhan.

3) Tingkat Suku Bunga SBI (X3)

Tingkat Suku Bunga SBI adalah nilai yang harus dibayar oleh bank indonesia kepada investor atas surat berharga yang diterbitkannya.

\section{Teknik pengumpulan data}

Sumber data yang digunakan dalam penelitian ini diperoleh dari situs resmi Bursa Efek Indonesia (BEI) yaitu www.idx.co.id. Badan Pusat Statistik (BPS) www.bps.go.id, dan situs resmi Bank Indonesia www.bi.go.id.

\section{Teknik Analisis Data}

\section{Uji asumsi klasik}

\section{1) Uji Normalitas}

Adalah pengujian tentang kenormalan distribusi data. Maksud data terdistribusi secara normal adalah bahwa data akan mengikuti bentuk distribusi normal. Distribusi normal data dengan bentuk distribusi normal dimana data memusat pada nilai rata-rata dan median (Purbayu dan Ashari, 2005:231).

2) Uji Multikolinearitas

Asumsi multikolinearitas menyatakan bahwa variabel independen harus terbebas dari gejala multikolinearitas. Gejala 
multikolinearitas adalah gejala korelasi antar variabel independen. Gejala ini ditunjukan dengan korelasi yang signifikan antar variabel independen (Purbayu dan Ashari, 2005:238). Menurut Sofyan (2011:36) menjelaskan nilai VIF (Variance Inflation Factor) $>10$ menunjukkan adanya gejala multikolinieritas. Model regresi yang baik adalah yang tidak terjadi multikolinieritas yang berarti nilai VIF < 10.

\section{3) Uji Autokorelasi}

Uji ini merupakan pengujian asumsi dalam regresi dimana variabel dependen tidak berkorelasi dengan dirinya sendiri. Maksudnya adalah bahwa nilai dari variabel dependen tidak berhubungan dengan nilai variabel itu sendiri, baik nilai periode sebelumnya atau nilai periode sesudahnya (Purbayu dan Ashari, 2005:240).

Salah satu ukuran dalam menentukan ada tidaknya masalah autokorelasi dengan uji Durbin-Watson (DW) dengan ketentuan sebagai berikut:

a) Terjadi autokorelasi positif, jika nilai DW di bawah -2 (DW <-2)

b) Tidak terjadi autokorelasi, jika nilai DW berada diantara -2 dan +2 atau -2 $\leq \mathrm{DW} \leq+2$

c) Terjadi autokorelasi negatif jika nilai DW di atas +2 atau DW $>+2$. (Sunyoto, 2007:105)

4) Uji Heterokedastisitas
Analisis uji heteroskedastisitas hasil output SPSS melalui grafik scatterplot antara $\mathrm{Z}$ prediction (ZPRED) yang merupakan veriabel bebas (sumbu $\mathrm{X}=\mathrm{Y}$ hasil prediksi) dan nilai residulanya (SRESID) merupakan variabel terikat (sumbu $\mathrm{Y}=\mathrm{Y}$ prediksi $-\mathrm{Y}$ riil). (Sunyoto, 2007:93)

\section{5) Uji Linieritas}

Uji linieritas digunakan untuk mengetahui apakah dalam model regresi terhadap hubungan yang linier atau tidak antara variabel bebas dengan variabel terikat. Kriteria pengujian model berbentuk linier diterima apabila nilai signifikansi yang diperoleh lebih dari nilai signifikansi 5\% dengan menggunakan uji Lagrange Multiplier. Uji Lagrage Multiplier menghubungkan nilai residual dengan nilai kuadrat variabel independennya (Ghozali, 2011:169).

\section{Uji Hipotesis}

1) Regresi Linier Sederhana

Regresi sederhana didasarkan pada hubungan fungsional ataupun kausal satu variabel independen dengan satu variabel dependen (Sugiyono, 2012:261). Model persamaan yang digunakan adalah sebagai berikut:

$\mathrm{Y}=\alpha+\mathrm{bX}$

Keterangan:

$\mathrm{Y}=$ Subjek dalam variabel independen

$\alpha=$ Harga $Y$ bila $X=0$

$\mathrm{b}=$ koefisien regresi linier sederhana 
$\mathrm{X}=$ subjek pada variabel independen.

a) Uji Parsial (uji t)

Uji $\mathrm{t}$ digunakan untuk menguji koefisien regresi secara parsial dari variabel independensinya.

$t=\frac{r(\sqrt{n}-2)}{\left(\sqrt{1}-r^{2}\right)}$

Keterangan:

$t=\mathrm{t}$ hitung

$\mathrm{r}=$ koefisien korelasi

$\mathrm{n}=$ jumlah ke-n

formulasi pengujian $\mathrm{t}$ sebagai berikut:

- jika signifikan $t_{\text {hitung }} \geq \mathrm{t}_{\text {tabel, }}$ maka $\mathrm{H}_{0}$ ditolak, yang berarti variabel independen secara parsial berpengaruh secara signifikan terhadap variabel dependen.

- Jika signifikan $t_{\text {hitung }}<\mathrm{t}_{\text {tabel, }}$ maka $\mathrm{H}_{0}$ diterima, berarti variabel independen secara parsial tidak berpengaruh secara signifikan terhadap variabel dependen. (Sugiyono, 2012:230)

b) Koefisien Determinasi $\left(R^{2}\right)$

Adalah suatu nilai yang menggambarkan seberapa besar perubahan atau variasi dari variabel dependen bisa dijelaskan oleh perubahan atau variasi dari variabel independen (Purbayu dan Ashari, 2005:144).

Dirumuskan sebagai berikut:

$\mathrm{R}^{2}=1-\frac{\sum(\mathrm{Y}-\overline{\mathrm{Y}})^{2}}{\sum(\mathrm{Y}-\overline{\mathrm{Y}})^{2}}$

Nilai $\mathrm{R}$ digunakan untuk mengetahui besarnya sumbangan variabel bebas yang diteliti terhadap variabel terikat. Besarnya $\mathrm{R}^{2}$ berada diantara $0-1$ atau $0<\mathrm{R}^{2}<1$.

2) Regresi Linier Berganda

Digunakan untuk mengetahui ada atau tidaknya pengaruh variabel bebas terhadap variabel terikat. Analisis ini digunakan untuk menjawab bagaimana pengaruh kurs/ nilai tukar rupiah, inflasi, dan suku bunga SBI terhadap IHS LQ-45. Model yang digunakan adalah sebagai berikut:

$\mathrm{Y}=\alpha+\mathrm{b}_{1} \mathrm{X}_{1}+\mathrm{b}_{2} \mathrm{X}+\mathrm{b}_{3} \mathrm{X}_{3}$

Keterangan:

$\mathrm{Y}=\mathrm{IHS}$ LQ-45

$\mathrm{X}_{1}=$ Kurs/ nilai tukar rupiah

$\mathrm{X}_{2}=$ Inflasi

$\mathrm{X}_{3}=$ Tingkat suku bunga SBI

$\alpha=$ Nilai Y jika $X=0$ (konstanta)

$\mathrm{b}=$ koefisien regresi linier berganda

(Sugiyono, 2012:294)

a) Uji Simultan (uji F)

Menguji keberartian regresi ganda dengan uji F. Uji F-statistik digunakan untuk menguji besarnya pengaruh dari seluruh variabel independen secara bersama-sama (simultan) terhadap variabel dependen. Rumus Uji F sebagai berikut:

$\mathrm{F}_{\mathrm{reg}}=\frac{R^{2(N-m-1)}}{m\left(1-R^{2}\right)}$

Keterangan:

$\mathrm{F}_{\text {reg }}=$ Harga $\mathrm{F}$

$\mathrm{N}$ = banyak sampel

$\mathrm{m}=$ banyak prediktor

$\mathrm{R}=$ koefisien korelasi antara kriteria dengan prediktor. 
Formulasi pengujian F sebagai berikut:

- Jika signifikan $F_{\text {hitung }} \geq \mathrm{F}_{\text {tabel, }}$, maka $\mathrm{H}_{\mathrm{o}}$ ditolak, yang berarti variabel independen secara simultan berpengaruh secara signifikan terhadap variabel dependen.

- Jika signifikan $F_{\text {hitung }}<\mathrm{F}_{\text {tabel }}$ maka $\mathrm{H}_{\mathrm{o}}$ diterima, berarti variabel independen secara bersama-sama tidak berpengaruh secara signifikan terhadap variabel dependen.

b) Koefisien Determinasi $\left(\mathrm{R}^{2}\right)$

Adalah suatu nilai yang menggambarkan seberapa besar perubahan atau variasi dari variabel dependen bisa dijelaskan oleh perubahan atau variasi dari variabel independen (Purbayu dan Ashari, 2005:144).

Dirumuskan sebagai berikut:

$\mathrm{R}^{2}=1-\frac{\sum(\mathrm{Y}-\overline{\mathrm{Y}})^{2}}{\sum(\mathrm{Y}-\overline{\mathrm{Y}})^{2}}$

Nilai $\mathrm{R}$ digunakan untuk mengetahui besarnya sumbangan variabel bebas yang diteliti terhadap variabel terikat. Jika $\mathrm{R}^{2}$ semakin besar (mendekati satu), maka sumbangan variabel bebas terhadap variabel terikat semakin besar. Sebaliknya apabila $\mathrm{R}^{2}$ semakin kecil (mendekati nol), maka besarnya sumbangan variabel bebas terhadap variabel terikat semakin kecil. Jadi besarnya $\mathrm{R}^{2}$ berada diantara $0-1$ atau $0<\mathrm{R}^{2}<1$.

\section{HASIL PENELITIAN \\ PEMBAHASAN}

Analisis Statistik Deskriptif

\begin{tabular}{lrrrr}
\multicolumn{5}{c}{ Statistics } \\
\hline & LQ_45 & KURS & INFLASI & $\begin{array}{c}\text { SUKU_BUNGA } \\
\text { SBI }\end{array}$ \\
\hline N $\quad \begin{array}{l}\text { Valid } \\
\text { Missing }\end{array}$ & 55 & 55 & 55 & 55 \\
Mean & 0 & 0 & 0 & 0 \\
& 616,4169 & 9460,699 & 5,0449 & 6,0138 \\
Median & & 6 & & \\
Mode & 659,0500 & 9290,240 & 4,6100 & 6,3000 \\
Std. Deviation & $249,01^{\mathrm{a}}$ & $8532,00^{\mathrm{a}}$ & 4,61 & $6,26^{\mathrm{a}}$ \\
Range & 146,8078 & 726,5065 & 1,58731 & 1,23556 \\
Minimum & 6 & 1 & 6,76 & 5,68 \\
Maximum & 611,03 & 3362,55 & 6,76 & 3,82 \\
\hline a. Multiple modes exist. The smallest value is shown & 9,50 \\
\hline
\end{tabular}

\section{Hasil Uji Asumsi Klasik}

\section{Uji Normalitas}

Uji normalitas merupakan pengujian tentang kenormalan distribusi data. Pada penelitian ini, uji normalitas dilakukan dengan melihat grafik PP Plot.

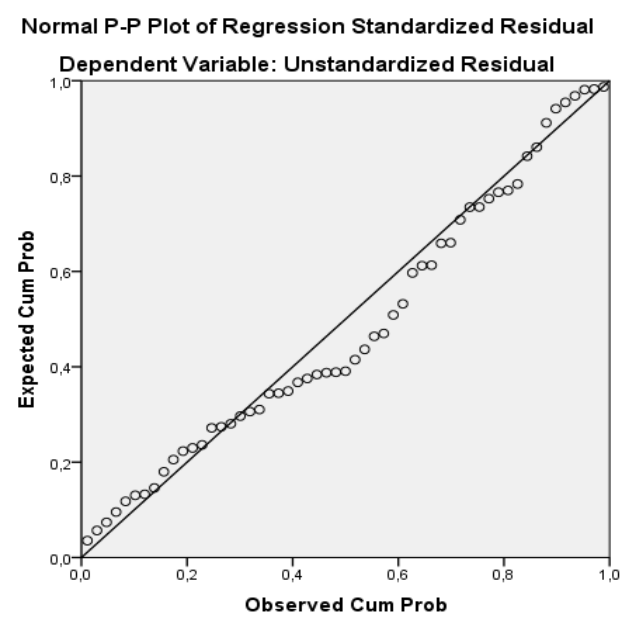

Gambar 5. Hasil Uji Normalitas dengan Normal P-P Plot

Pada grafik PP Plot diatas, kesamaan antara nilai probabilitas harapan dan probabilitas pengamatan ditunjukkan dengan garis diagonal yang merupakan 
perpotongan antara garis probabilitas harapan dan probabilitas pengamatan. Dari garis tersebut jika terlihat bahwa nilai Plot PP terletak disekitar garis diagonal. Jadi dapat disimpulkan bahwa data terdistribusi normal. Sedangkan hasil pengujian menggunakan Uji Kolmogorov-Smirnov sebagai berikut:

Tabel 5. Hasil Uji Normalitas

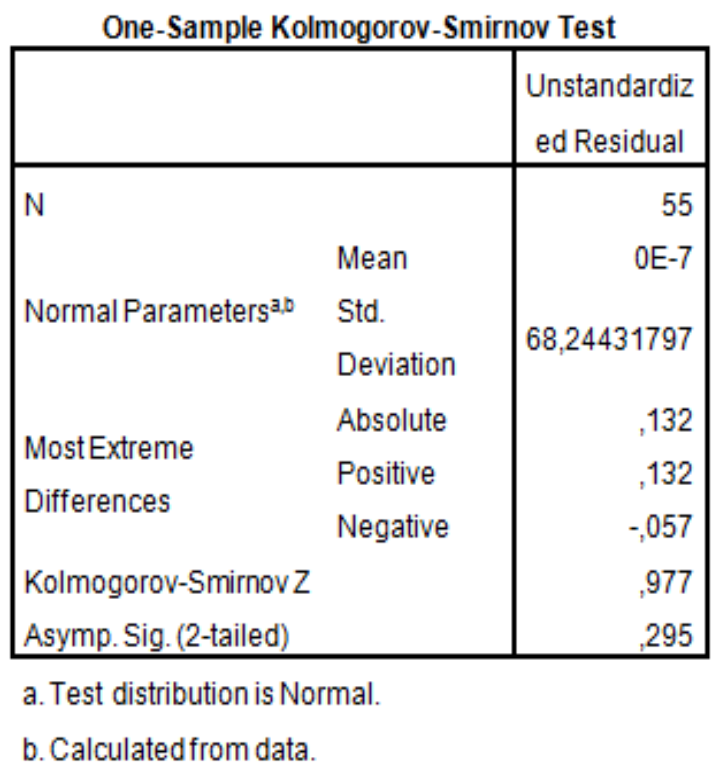

Dari tabel diatas dapat dilihat bahwa data dalam penelitian ini terdistribusi secara normal. Hal tersebut dapat dinilai dengan melihat nilai signifikansi 0,295 yang diperoleh lebih besar dari nilai signifikansi yang ditetapkan yaitu 0,05. Dari tabel diatas dapat disimpulkan bahwa data penelitian ini telah terdistribusi secara normal.

\section{Uji Multikolinieritas}

Uji ini dilakukan untuk mengetahui ada tidaknya gejala multikolinieritas, yaitu gejala korelasi antar variabel independen. Suatu model regresi harus terbebas dari gejala multikolinieritas. Pada penelitian ini, uji multikolinieritas dilakukan dengan menggunakan metode VIF (Variance Inflation Factor). Hasil uji multikolinieritas menggunakan SPSS adalah sebagai berikut:

Tabel 6. Hasil Uji Multikolinieritas

\begin{tabular}{lll}
\hline Variabel & $\begin{array}{c}\text { VIF } \\
\text { hitung }\end{array}$ & Kesimpulan \\
\hline Kurs & 1,180 & Nonmultikolinieritas \\
\hline Inflasi & 1,315 & Nonmultikolinieritas \\
\hline Tingkat & 1,290 & Nonmultikolinieritas \\
Suku Bunga & & \\
SBI & & \\
\hline
\end{tabular}

Dari tabel tersebut nilai VIF hitung tiap variabel independen $<10$. Dengan demikian dapat disimpulkan bahwa tidak terjadi gejala multikolinieritas (nonmultikolinieritas).

\section{Uji Autokorelasi}

Uji Autokorelasi merupakan pengujian asumsi dalam regresi dimana variabel dependen tidak berkorelasi dengan dirinya sendiri. Uji autokorelasi dalam penelitian ini menggunakan uji Durbin-Watson (DW) dengan ketentuan sebagai berikut:

a. Terjadi autokorelasi positif, jika nilai DW dibawah -2

b. Tidak terjadi autokorelasi jika nilai DW berada diantara -2 dan +2

c. Terjadi autokorelasi negative jika nilai DW di atas +2 .

Berdasarkan uji diatas, diperoleh nilai Durbin-Watson sebesar 0,384. 
Dengan demikian dapat disimpulkan bahwa pada data penelitian ini tidak terjadi autokorelasi karena nilai DW sebesar 0,384 berada diantara -2 dan +2 .

\section{Uji Heterokedastisitas}

Asumsi heterokedastisitas adalah asumsi dalam regresi dimana varian dalam residual tidak sama untuk satu pengamatan kepengamatan lain. Salah satu asumsi yang harus dipenuhi dalam regresi adalah asumsi heterokedastisitas dimana varians residual tidak boleh sama antara satu pengamatan dengan pengamatan lain sehingga varians residual tersebut tidak membentuk pola tertentu. Pada penelitian ini, uji heterokedastisitas dilakukan dengan metode scatterplot.

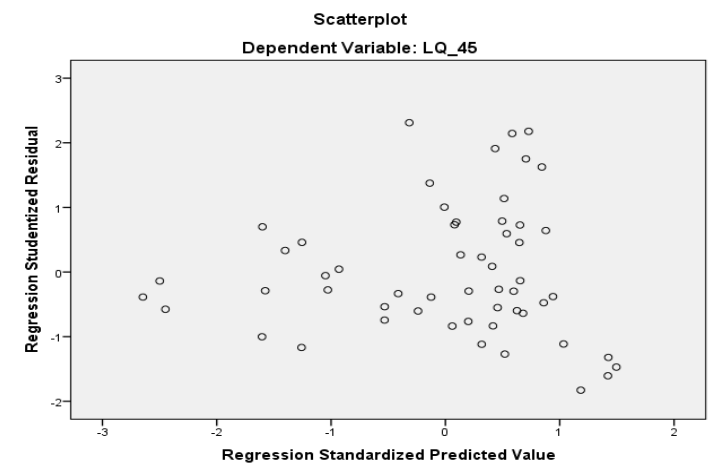

Gambar 6. Hasil Uji Heterokesdisitas Menggunakan Scatterplot

Dari hasil tersebut terlihat bahwa penyebaran residual adalah tidak teratur. Hal tersebut dapat dilihat pada plot yang terpencar dan tidak membentuk pola tertentu. Dengan demikian dapat disimpulkan persamaan regresi memenuhi asumsi heterokedastisitas.

\section{Uji Linieritas}

Uji ini digunakan untuk mengetahui apakah dalam model regresi terhadap hubungan yang linier atau tidak antara variabel bebas dengan variabel terikatnya. Penelitian ini menggunakan uji Lagrange Multiplier untuk memperoleh nilai $\mathrm{c}^{2}$ hitung atau ( $\left.\mathrm{n} \times \mathrm{R}^{2}\right)$.

Tabel 7. Hasil Uji linieritas

\begin{tabular}{|c|c|c|c|}
\hline \multicolumn{4}{|c|}{ Model Summaryb } \\
\hline $\begin{array}{l}\text { Mo } \\
\text { del }\end{array}$ & $\begin{array}{c}\mathrm{R} \\
\text { Squar } \\
\mathrm{e}\end{array}$ & $\begin{array}{c}\text { Adjusted } \\
\text { R } \\
\text { Square }\end{array}$ & $\begin{array}{l}\text { Std. Error of the } \\
\text { Estimate }\end{array}$ \\
\hline $\begin{array}{l}1 \\
\text { a. P } \\
\text { SUl } \\
\text { b. D } \\
\text { Res }\end{array}$ & $\begin{array}{l}\text {,033 }{ }^{\mathrm{a}}, 001 \\
\text { dictors: (Cons } \\
\text { BUNGA_SB } \\
\text {-endent Varia } \\
\text { ual }\end{array}$ & $\begin{array}{l}\text { tant), } \\
\text { 2, KURS } \\
\text { 2, KU: Unstar }\end{array}$ & $\begin{array}{l}\text { 70,18509817 } \\
\text { 2, INFLASI_2 } \\
\text { dardized }\end{array}$ \\
\hline
\end{tabular}

Dari tabel diatas menunjukkan bahwa nilai $\mathrm{R}^{2}$ sebesar 0,001 dengan jumlah $\mathrm{n}$ observasi 55 , maka besarnya $\mathrm{c}^{2}$ hitung $=55 \times 0,001=0,055$. Nilai ini dibandingkan dengan $\mathrm{c}^{2}$ tabel dengan $\mathrm{df}=$ $\mathrm{n}-\mathrm{k}=55-5=50$ dan tingkat signifikasi 0,05 maka didapat nilai $\mathrm{c}^{2}$ tabel 67,51. Oleh karena nilai $\mathrm{c}^{2}$ hitung $<\mathrm{c}^{2}$ tabel $(0,055<67,51)$ maka dapat disimpulkan model tersebut memenuhi syarat linieritas.

\section{Hasil Uji Hipotesis}

Tabel 8. Hasil Regresi Sederhana Hipotesis Pertama

\begin{tabular}{|l|l|l|l|l|l|l|}
\hline Model & $\begin{array}{l}\text { Variabel } \\
\text { Independen }\end{array}$ & $\begin{array}{l}\text { Koef } \\
\text { Reg }\end{array}$ & t hitung & t tabel & $\begin{array}{l}\mathrm{R} \\
\text { square }\end{array}$ & Sig. \\
\hline \multirow{2}{*}{1} & (Constant) & 1718,948 & 7,989 & &, 333 & \\
\cline { 2 - 7 } & Kurs &,- 117 & $-5,139$ & 1,674 & &, 000 \\
\hline
\end{tabular}


Tabel 9. Hasil Regresi Sederhana Hipotesis Kedua

\begin{tabular}{|l|l|l|l|l|l|l|}
\hline Model & $\begin{array}{l}\text { Variabel } \\
\text { Independen }\end{array}$ & $\begin{array}{l}\text { Koef } \\
\text { Reg }\end{array}$ & thitung & t tabel & $\begin{array}{l}\mathrm{R} \\
\text { square }\end{array}$ & Sig. \\
\hline 2 & (Constant) & 665,316 & 9,965 & &, 011 & \\
\cline { 2 - 7 } & Inflasi & $-9,693$ &,- 767 & 1,674 & &, 446 \\
\hline
\end{tabular}

Tabel 10. Hasil Regresi Sederhana Hipotesis Ketiga

\begin{tabular}{|l|l|l|l|l|l|l|}
\hline Model & $\begin{array}{l}\text { Variabel } \\
\text { Independen }\end{array}$ & $\begin{array}{l}\text { Koef } \\
\text { Reg }\end{array}$ & t hitung & $t$ tabel & $\begin{array}{l}\mathrm{R} \\
\text { square }\end{array}$ & Sig. \\
\hline 3 & (Constant) & 1140,534 & 16,752 & &, 538 & \\
\cline { 2 - 7 } & $\begin{array}{l}\text { Suku } \\
\text { Bunga SBI }\end{array}$ & $-87,152$ & $-7,856$ & 1,674 & &, 000 \\
\hline
\end{tabular}

Tabel 11. Hasil Regresi Ganda

\begin{tabular}{|l|l|l|r|r|r|r|l|l|}
\hline Model & $\begin{array}{l}\text { Variabel } \\
\text { Independen }\end{array}$ & $\begin{array}{l}\text { Koef } \\
\text { Reg }\end{array}$ & thitung & $\begin{array}{l}\text { t tabel } \\
\text { Adjust } \\
R \\
\text { Square }\end{array}$ & F hit & $\begin{array}{l}\text { F } \\
\text { tabel }\end{array}$ & Sig. \\
\hline 4 & (constant) & 1872,963 & 14,844 & 1,674 &, 771 & 61,671 & 2,79 & \\
\cline { 2 - 9 } & Kuls & $;, 095$ & $\cdot 10,208$ & 1,674 & & & &, 000 \\
\hline & Inflasi & 35,912 & $-6,647$ & 1,674 & & & &, 000 \\
\cline { 2 - 8 } & $\begin{array}{l}\text { Suku } \\
\text { Bunga SBI }\end{array}$ & $-89,675$ & 5,203 & 1,674 & & & &, 000 \\
\hline
\end{tabular}

\section{PEMBAHASAN}

Pengaruh Kurs/ Nilai Tukar Rupiah terhadap Indeks Harga Saham LQ-45

Berdasarkan uji parsial, kurs/ nilai tukar rupiah berpengaruh negatif tidak signifikan terhadap IHS LQ-45. Hal ini ditujukkan dari hasil koefisien regresi sebesar -0,117 dan nilai t hitung sebesar 5,139 lebih besar dibanding $\mathrm{t}$ tabel. Dengan bantuan SPSS 20 dapat diketahui bahwa koefisien determinasi $\left(\mathrm{R}^{2}\right)$ sebesar 0,333 yang berarti bahwa 33,3\% IHS LQ45 dipengaruhi oleh kurs, sedangkan $66,7 \%$ dipengaruhi oleh faktor lain. Hasil penelitian ini mempertegas penelitian yang dilakukan oleh Ade Trisnawati (2012) dengan judul pengaruh suku bunga Sertifikat Bank Indonesia, Nilai Kurs Dollar, Dan Indeks Hang Seng Terhadap Indeks Harga Saham Gabungan Di Bursa Efek Indonesia Periode Tahun 2007-2011 yang menyatakan kurs/ nilai tukar rupiah berpengaruh negatif terhadap IHSG dan hasil penelitian Yuni Kemala Sari (2011) dengan judul Pengaruh Tingkat Suku Bunga Sertifikat Bank Indonesia, Indeks Saham Hang Seng, Kurs Dollar dan Indeks Saham Dow Jones Industrial Average terhadap Indeks Harga saham gabunagn di Bursa Efek Indonesia Periode Tahun 20082010 yang menyatakan kurs berpengaruh negatif terhadap IHSG.

Hasil penelitian ini menyatakan bahwa kurs berpengaruh negatif terhadap IHS LQ-45. Hubungan negatif antara kurs dengan indeks harga saham sesuai dengan teori yang dikemukakan oleh Tandelilin (2007) yang menyatakan bahwa salah satu faktor makro ekonomi berupa nilai tukar mata uang (exchage rate) terbukti mempunyai pengaruh terhadap perkembangan investasi dipasar modal selain itu menurut Robert Ang (dalam Ardian, 2010) yang menyatakan bahwa dengan menurunnya nilai tukar rupiah terhadap dollar berarti menunjukkan melemahnya nilai tukar rupiah. Bagi seorang investor, menurunnya nilai tukar 
rupiah terhadap dollar AS menandakan bahwa kondisi perekonomian Indonesia sedang tidak baik. Hal tersebut tentunya memberikan resiko kepada investor yang akan berinvestasi di pasar modal indonesia. Investor tentu saja akan menghindari resiko tersebut dan akan menjual saham sampai kondisi perekonomian dirasa semakin membaik. Hal semacam inilah yang dapat mengakibatkan penurunan indeks harga saham LQ-45 di BEI.

\section{Pengaruh Inflasi terhadap IHS LQ-45}

Berdasarkan uji parsial, inflasi berpengaruh negatif tidak signifikan terhadap IHS LQ-45. Hal ini ditunjukkan dengan nilai koefisien regresi sebesar 9,693 dan $t$ hitung sebesar -0,767 lebih kecil dibandingkan dengan $\mathrm{t}$ tabel. Dengan bantuan SPSS 20 dapat diketahui bahwa koefisien determinasi $\left(\mathrm{R}^{2}\right)$ sebesar 0,011 yang berarti bahwa 1,1\% IHS LQ-45 dipengaruhi oleh inflasi, sedangkan 98,9\% dipengaruhi oleh faktor lain. Hasil ini sesuai dengan penelitian Erni Isnawati (2010) dengan judul Pengaruh Faktor Makro Ekonomi Terhadap Indeks Harga Saham LQ-45 Periode Tahun 2007-2010 yang menyatakan inflasi berpengaruh negatif terhadap IHS LQ-45.

Hasil penelitian ini sesuai dengan teori yang dikemukakan oleh Tandelilin (2007) yang menyatakan bahwa Selain kurs, inflasi juga mempunyai pengaruh negatif terhadap pergerakan indeks harga saham. Pengaruh inflasi terhadap indeks harga saham juga dikemukakan oleh Alwi (2003) yang mengemukakan bahwa inflasi merupakan salah satu faktor eksternal (lingkungan makro) yang mempunyai pengaruh terhadap pergerakan indeks harga saham di BEI. Hasil dari penelitian ini terbukti bahwa inflasi mempunyai pengaruh negatif terhadap pergerakan indeks harga saham LQ-45. Dengan semakin tingginya angka inflasi, maka perekonomian semakin memburuk dan hal ini akan berdampak pada pergerakan indeks harga saham di pasar modal.

\section{Pengaruh Tingkat Suku Bunga SBI terhadap IHS LQ-45.}

Berdasarkan uji parsial, tingkat suku bunga SBI berpengaruh negatif dan tidak signifikan. Terhadap IHS LQ-45. Hal ini ditunjukkan dengan nilai koefisien regresi sebesar -87,152 dan nilai t hitung sebesar 7,856 lebih kecil dibanding t tabel. Dengan bantuan SPSS 20 dapat diketahui bahwa koefisien determinasi $\left(\mathrm{R}^{2}\right)$ sebesar 0,538 yang berarti bahwa 53,8\% IHS LQ-45 dipengaruhi oleh tingkat suku bunga SBI, sedangkan 46,2\% dipengaruhi oleh faktor lain. Hasil penelitian ini memperkuat penelitian Ade Trisnawati (2012) dengan judul Pengaruh Suku Bunga Sertifikat Bank Indonesia, Nilai Kurs Dollar, Dan Indeks Hang Seng Terhadap Indeks Harga Saham Gabungan Di Bursa Efek Indonesia 
Periode Tahun 2007-2011. Penelitian Yuni Kemala Sari (2011) dengan judul Pengaruh Tingkat Suku Bunga Sertifikat Bank Indonesia, Indeks Saham Hang Seng, Kurs Dollar dan Indeks Saham Dow Jones Industrial Average terhadap Indeks Harga saham gabunagn di Bursa Efek Indonesia Periode Tahun 2008-2010 yang menyatakan tingkat suku bunga SBI berpengaruh negatif terhadap IHSG, dan penelitian Erni Isnawati (2010) dengan judul Pengaruh Faktor Makro Ekonomi Terhadap Indeks Harga Saham LQ-45 Periode Tahun 2007-2010. Yang menyatakan tingkat suku bunga SBI berpengaruh negatif terhadap IHS LQ-45.

Menurut Alwi (2003) perubahan suku bunga tabungan dan deposito merupakan salah satu faktor eksternal (lingkungan makro) yang mempengaruhi pergerakan indeks harga saham. Selain itu menurut Tandelilin (2007) tingkat suku bunga merupakan salah satu faktor ekonomi makro yang secara empiris telah terbukti mempunyai pengaruh terhadap indeks harga saham. Hasil penelitian ini menunjukkan bahwa tingkat suku bunga SBI berpengaruh negatif terhadap IHS LQ45. SBI merupakan salah satu instrumen moneter yang dilakukan oleh Bank Indonesia. Upaya pemerintah menaikkan tingkat suku bunga SBI yaitu untuk menjaga stabilitas moneter dan mengurangi tekanan nilai tukar Rupiah terhadap Dolar AS yang berdampak buruk bagi pasar modal karena investor akan lebih tertarik untuk berinvestasi dengan membeli SBI daripada membeli saham dan perubahan harga saham tersebut akan tercermin pada penurunan Indeks Harga Saham terutama IHS LQ-45.

\section{Pengaruh Kurs/ Nilai Tukar Rupiah, Inflasi dan Tingkat Suku Bunga SBI terhadap IHS LQ-45 secara simultan (bersama-sama)}

Dari tabel tersebut dapat dilihat bahwa koefisien determinasi $\left(\mathrm{R}^{2}\right)$ adalah sebesar 0,771 yang berarti sebanyak $77,1 \%$ variasi atau perubahan IHS LQ-45 dapat dijelaskan oleh perubahan variasi dari kurs/ nilai tukar rupiah, inflasi dan tingkat suku bunga SBI, sedangkan 22,9\% dijelaskan oleh faktor-faktor lain diluar penelitian ini. Dari tabel tersebut juga dapat dilihat bahwa diperoleh nilai $F$ hitung sebesar 61,671 dengan nilai signifikansi 0,000 . Penelitian ini menggunakan nilai signifikansi $5 \%$ dan degree of freedom (df) sebesar $(\mathrm{k}-1)=3$ dan $(n-5)=51$ sehingga diperoleh $F$ tabel sebesar 2,79. Dengan demikian dapat diketahui bahwa nilai $\mathrm{F}$ hitung lebih besar dari $F$ tabel $(61,671>2,79)$ dan nilai signifikansi lebih kecil dari alpha 5\% $(0,000<0,0)$.

Dengan demikian dapat disimpulkan bahwa kurs/ nilai tukar rupiah, inflasi dan tingkat suku bunga memang mempunyai 


\section{JURNAL NOMINAL / VOLUME VI NOMOR 1 / TAHUN 2017}

pengaruh terhadap pergerakan indeks harga saham LQ-45 seperti yang dikemukakan oleh Tandelilin (2007) menyatakan bahwa faktor - faktor ekonomi makro secara empiris telah terbukti mempunyai pengaruh terhadap kondisi pasar modal di beberapa negara. Faktor -faktor tersebut yaitu pertumbuhan Produk Domestik Bruto (PDB), laju pertumbuhan inflasi, tingkat suku bunga dan nilai tukar mata uang (exchange rate). Dalam penelitian ini kurs/ nilai tukar rupiah, inflasi dan tingkat suku bunga SBI berpengaruh negatif terhadap indeks harga saham LQ-45.

\section{SIMPULAN DAN SARAN}

\section{Kesimpulan}

Penelitian ini bertujuan untuk mengetahui pengaruh Kurs/ Nilai Tukar Rupiah, Inflasi dan Tingkat Suku Bunga SBI terhadap Indeks Harga Saham LQ-45 periode tahun 2009-2013. Berdasarkan hasil analisis, maka kesimpulan yang dapat diambil adalah sebagai berikut:

a. Kurs/ nilai tukar rupiah berpengaruh negatif dan signifikan terhadap Indeks Harga Saham LQ-45. Hal ini di tunjukkan dengan persamaan regresi yaitu IHS LQ$45=1718,948-0,117$ (Kurs), nilai koefisien regeresi bernilai negatif $(-0,117)$ dan nilai sig t sebesar 0,000 lebih kecil dari nilai probabilitas yang telah ditentukan 0,05 atau $0,000<0,05$ menunjukkan pengaruh yang signifikan terhadap IHS LQ-45.

b. Inflasi berpengaruh negatif dan tidak signifikan terhadap Indeks Harga Saham LQ-45. Hal ini di tunjukkan dengan persamaan regresi yaitu IHS LQ-45 = 665,316 - 9,693(Inflasi), nilai koefisien regeresi bernilai negatif $(-0,693)$ dan nilai sig t sebesar 0,446 lebih besar dari nilai probabilitas yang telah ditentukan 0,05 atau 0,446 > 0,05 menunjukkan pengaruh yang tidak signifikan terhadap IHS LQ-45. c. Tingkat suku bunga SBI berpengaruh negatif dan signifikan terhadap IHS LQ45. Hal ini ditunjukkan dengan persamaan regresi yaitu IHS LQ-45 = 1140,534 87,152(SBI), nilai koefisien regeresi bernilai negatif $(-87,152)$ dan nilai sig $t$ sebesar 0,000 lebih kecil dari nilai probabilitas yang ditentukan 0,05 atau $0,000<0,05$ menunjukkan pengaruh yang signifikan terhadap IHS LQ-45.

d. Kurs/ nilai tukar rupiah, inflasi, tingkat suku bunga SBI secara simultan berpengaruh signifikan terhadap IHS LQ45. Hal ini ditunjukkan dengan persamaan garis regresi yaitu IHS LQ-45 = 1872,9630,095(Kurs) + 35,912(Inflasi) 89,675(SBI), nilai sig $\mathrm{F}$ sebesar 0,000 lebih kecil daripada nilai probabilitas yang ditentukan yaitu 0,05 menunjukkan pengaruh yang signifikan terhadap Indeks Harga Saham LQ-45. 


\section{JURNAL NOMINAL / VOLUME VI NOMOR 1 / TAHUN 2017}

\section{Saran}

Berdasarkan kesimpulan di atas, maka saran-saran yang dapat diberikan berkaitan dengan perkembangan pasar modal di Indonesia adalah sebagai berikut:

a. Bagi Investor dan Calon Investor Perubahan kurs/ nilai tukar rupiah, inflasi, dan tingkat suku bunga SBI sebagai faktor yang mempengaruhi harga dan indeks harga saham akan mempunyai dampak yang berbeda dari satu industri ke industri lain, sehingga implikasinya bagi investor adalah dalam berinvestasi hendaknya memperhatikan pembentukan portofolio yang ada untuk mengurangi resiko investasi yang mungkin ditanggung.

b. Bagi Perusahaan

Mengingat dampak inflasi yang sulit dikendalikan dan membawa dampak negatif pada pasar modal, sebaiknya perusahaan terus berusaha meningkatkan strategi-setrateginya sehubung dengan kinerja perusahaan sehingga harga sahamnya tetap terjaga dan bisa meminimalkan dampak inflasi yang mungkin ditanggung.

c. Bagi Penelitian Selanjutnya

Sebaiknya variabel-variabel atau faktor lain yang diduga mempengaruhi pergerakan indeks harga saham ditambah misalkan tentang faktor politik agar hasil penelitian yang diperoleh lebih tepat.

\section{DAFTAR PUSTAKA}

Abdul Halim. (2005). Analisis Investasi. Jakarta: Salemba Empat.

Ade Trisnawati. (2012). "Pengaruh Suku Bunga Sertifikat Bank Indonesia, Nilai Kurs Dollar, Dan Indeks Hang Seng Terhadap Indeks Harga Saham Gabungan Di Bursa Efek Indonesia Periode Tahun 20072011". Skripsi. Manajemen FE UNY.

Adrian Agung Wicaksono. (2010). Analisis Pengaruh Tingkat Suku Bunga SBI, Harga Minyak Dunia, Harga Emas Dunia, Kurs Rupiah, Indeks Nikkei 225, dan Indeks Dow Jones terhadap IHSG". Tesis. Pasca Sarjaan UNDIP.

Boediono. (2005). Ekonomi Makro Edisi 4. Yogyakarta: BPFE.

Danang Sunyoto. (2007). Analisis Regresi dan Korelasi Bivariat. Yogyakarta: Amara Books.

Djipto Darmaji dan Hendy M. Fakhruddin. (2006). Pasar Modal Di Indonesia: Pendekatan Tanya Jawab Edisi 2. Jakarta: Salemba Empat.

Eduardus Tandelilin. (2007). Analisis Investasi Dan Manajemen Portofolio. Yogyakarta: BPFE.

Erni Isnawati. (2010). "Pengaruh Faktor Makro Ekonomi Terhadap Indeks Harga Saham LQ-45 Periode Tahun 2007-2010”. Skripsi. Manajemen FE UNY.

Imam Ghozali. (2011). Aplikasi Analisis Multivariate dengan Program IBM SPSS 20. Edisi 5. Semarang: Badan Penerbitan Universitas Diponegoro. 
Jogiyanto Hartono. (2009). Teori Portofolio dan Analisis Investasi. Yogyakarta: BPFE.

Jurnal manajemen, bahan kuliah manajemen http://jurnalsdm.blogspot.com/

-http://jurnal-

sdm.blogspot.com/2009/10/faktorfaktor-yang-mempengaruhi.html.

Kasmir. (2010). Dasar-dasar Perbankan. Jakarta: Rajawali Pers.

Ktut Silvanita Mangani. (2009). Bank dan Lembaga Keuangan Lain. Jakarta: Penerbit Erlangga.

Malayu S. P. Hasibuan. (2006). Dasardasar Perbankan. Jakarta: PT. Bumi Aksara.

Mohamad Samsul. (2006). Pasar Modal dan Manajemen Portofolio. Surabaya: Penerbit Erlangga.

Mudrajad Kuncoro. (2003). Metode Riset Untuk Bisnis dan Ekonomi. Jakarta: Penerbit Erlangga.

N. Gregory Mankiw. (2004). Prisciples Of Economics: Pengantar Ekonomi Makro. Jakarta: Salemba Empat.

Norphin. (2010). Ekonomi Moneter. Yogyakarta: BPFE. (1999). Ekonomi Internasioanal.

Yogyakarta. BPFE.

Nur Indriantoro dan Bambang Supomo. (2009). Metodologi Penelitian
Bisnis Untuk Akuntansi Dan Manajemen. Yogyakarta: BPFE.

Purbayu Budi Santoso dan Ashari. (2005). Analisis Statistik Dengan Microsoft Excel Dan SPSS. Yogyakarta: Penerbit ANDI.

Situs Web Resmi Bank Indonesia: www.bi.go.id,

Situs Web Resmi Bursa Efek Indonesai: www.idx.co.id

Sadono Sukirno. (2011). Teori Pengantar Makro ekonomi. Jakarta: Rajawali Pers.

Sigit Triandaru dan Totok Budi Santoso.(2008). Bank dan Lembaga Keuangan Lain. Jakarta: Salemba Empat.

Suad Husnan. (2001). Dasar-Dasar Teori Portofolio dan Analisis Sekuritas. Yogyakarta: AMP YKPN.

Sugiyono. (2012). Statistik Untuk Penelitian. Bandung: Alfabeta.

Supardi. (2005). Metodologi Penelitian Ekonomi Dan Bisnis. Yogyakarta: UII Press.

www.id.wikipedia.com.

Yuni Kemala Sari. (2011). "pengaruh Tingkat Suku Bunga Sertifikat Bank Indonesia, Indeks Saham Hang Seng, Kurs Dollar dan Indeks Saham Dow Jones Industrial Average terhadap Indeks Harga saham gabunagn di bursa efek indonesia periode tahun 20082010”. Skripsi. FE UNY. 